\title{
Australia's Merger Policy and the Caltex/Ampol Merger Case
}

\author{
Sandra Navalli
}

$\mathbf{R}$

ECENT events have signalled the emergence of the Australian Competition and Consumer Commission (ACCC), formerly the Trade Practices Commission (TPC), as a powerful and active regulator. The reviews of the ACCC's draft merger guidelines by the Industry Commission (IC) and the ACCC itself make a closer look at the usefulness of the current guidelines and their application timely. Under the current rules, the ACCC has intervened in mergers in prominent industries such as petrol, banking and pay TV. The Caltex/Ampol merger in 1995 provides a useful example of the factors the ACCC may take into account in administering the merger test. It also shows how such cases are resolved by parties giving enforceable undertakings rather than through litigation.

\section{Current Merger Test and Underlying Policy}

From 1977 to 1992, a merger was unlawful if it created or enhanced a position of 'market dominance'. In 1992, following the recommendations of the Senate Standing Committee on Legal and Constitutional Affairs (1991), Section 50 of the Trade Practices Act (TPA) was amended and the 'market dominance' test was replaced by a 'substantially lessening competition' test, which imposes a lower threshold of additional market power following a merger. Judicial interpretation of the 'dominance' test had allowed concentration up to the point of duopoly, even if significant barriers to entry existed. ${ }^{1}$ The threshold was breached if the acquiring firm could control the market; but, as long as the relevant market consisted of at least two large firms, it was thought that no firm could exercise dominance. Some commentators judged that the test paid too much attention to structure, concentration and market share, and argued that more emphasis should be placed on competitive pressures faced by firms in the industry and on behavioural market analysis (for example, Tonking, 1992:292).

The amended TPA applies to acquisitions as well as mergers: a corporation may not 'directly or indirectly acquire shares or assets if the acquisition would have the effect of substantially lessening competition in a market'. The acquisition of shares or assets may be by way of purchase, exchange, taking on lease, on hire or

\footnotetext{
${ }^{1}$ TPC v Ansett Transport Industries (Operations) Pty Ltd \& Ors (1978) ATPR 40-071.
}

Sandra Navalli is a recent economics honours graduate at The Australian National University. 
hire purchase. 'Assets' are undefined in the Act, but ordinary legal interpretation suggests that they would probably include both real (land) and personal property.

Market power may manifest itself in the ability to increase prices above competitive levels or to affect unduly the quantity and quality of goods. Unlike conduct provisions, which primarily use evidence of a firm's actual behaviour, the TPA requires the ACCC to forecast the potential effects of a merger. Since this involves a margin of error, more caution is required before any decision to intervene is made.

Section $50(3)$ of the TPA lists the following set of non-exclusive factors that must be taken into account in judging whether a proposed acquisition will result in a substantial lessening of competition:

- the actual and potential level of import competition in the market;

- the height of barriers to entry to the market;

- the level of concentration in the market;

- the degree of countervailing power in the market;

- the likelihood that the acquisition would result in the acquirer being able to increase significantly and sustainably prices or profit margins;

- the extent to which substitutes are available in the market or are likely to be available in the market;

- the dynamic characteristics of the market, including growth, innovation and product differentiation;

- the likelihood that the acquisition would result in the removal from the market of a vigorous and effective competitor; and

- the nature and extent of vertical integration in the market.

The Act does not make clear the weights that are to be assigned to these factors (Pasternak, 1994:89). But the ACCC's Draft Merger Guidelines outline the following five-step approach for evaluating mergers:

1. Market definition.

2. Concentration thresholds: if the merger results in the four largest firms having a market share of 75 per cent or more and the merged firm having a market share over 15 per cent; or if the four largest firms have less than 75 per cent and the merged firm has 40 per cent or more, then the TPC will proceed to the next step. 


\section{Import competition.}

4. Barriers to entry.

5. Other structural and behavioural market features.

Whereas the Act treats the threat of imports and barriers to entry as more important than concentration ratios, the ACCC's five-step approach applies these tests in reverse order. This reflects not only the ease of calculating concentration ratios but also a belief that concentration is a necessary but not sufficient condition for the exercise of market power (Hay \& Walker, 1993:43).

Companies may go ahead with mergers and run the risk of an ACCC challenge in the courts. Alternatively, if a proposed merger clearly would result in a substantial lessening of competition, they may formally submit it for authorisation to the ACCC (s.88(9)), which will apply a 'public benefit' test (s.90(9) and (9A)). The concept of 'public benefit' is more fully described in the ACCC's Merger Guidelines. Such public benefits include efficiency gains arising from economies of scale or scope in production, distribution and/or marketing; industrial rationalisation, adjusting capacity to demand and/or reducing unit costs; investment in more efficient plant and equipment or distribution facilities; significant increases in real exports; significant substitution of domestic products for imported goods; expansion of employment or prevention of unemployment in efficient industries; other benefits to the public; and international competitiveness concerns.

\section{The Economics of 'Substantial Lessening of Competition'}

The statutory 'substantial lessening of competition' test seems on the face of it to be economically sound. But the legislative factors contained in s.50(3) ${ }_{2}$ are similar to those used to determine 'market dominance' in previous court cases. ${ }^{2}$ In practice, therefore, the analytical process for the new test appears to be virtually identical to that for the old one, the difference lying in the lower threshold (Pasternak, 1994:99). Nevertheless, the focus of inquiry has widened with the new guidelines. According to the explanatory memorandum the Trade Practices Legislation (Amendment) Act 1992, the new test examines changes to the amount of competition in the entire relevant market. Whereas the current merger guidelines focus on the market share of the four largest firms, the older 1986 merger guidelines based on the old dominance test concentrated on the market share of the merged firm, with a market-share threshold of 45 per cent or a share which exceeded the nearest competitor by at least 15 per cent.

Yet the criterion of 'substantial lessening of competition' remains vague and fails to provide a clear yardstick. The explanatory memorandum defines 'substantially' as connoting an effect on competition which is 'real or of substance, not necessarily one which must be large or weighty'. However, as Deane J points 
out, 'substantial' is not only ambiguous, but 'it is a word calculated to conceal a lack of precision'. 'Under the old test, the meaning of 'dominance' was similarly vague. Although 'dominate' was interpreted as something less than 'control', it did mean 'having a commanding influence on'.'

If prices are used as a proxy for market power, how much do prices have to rise after the merger for it to be said that competition is substantially lessened? The only certain test in the draft guidelines relates to concentration. But a concentration ratio which measures the sales of the four largest firms ignores their relative size and the total number of firms in that market. In the United States, the HerfindahlHirschman Index (HHI) is used, which measures absolute and relative market concentration by summing the squared market shares of all firms. The $\mathrm{HHI}$, if calculated as a ratio, would produce a number between zero (perfect competition) and one (monopoly) (Laine, 1995). In Australia, with its smaller market, the HHI would generally result in high scores and therefore be of limited use. Difficulties in drafting more precise rules include lack of data, limitations in econometric methods and the need to provide simple rules for the wider community (Prices Surveillance Authority, 1995). But a balance needs to be maintained between flexibility and the uncertainty created by rules that confer too wide a discretion on the ACCC. The five-step test gives an impression of independent and discrete steps, whereas in reality significant overlap occurs: for example, imports may influence market definition.

\section{Protecting Consumers}

The ACCC's increased profile and media releases suggest that it is adopting a stronger consumer protection role (Fels, 1995), implying a downgrading of the efficiency benefits to firms and shareholders from rationalisation in favour of benefits to consurners in terms of lower prices. But efficiency gains may manifest themselves in consumer gains, in producer gains or in any combination. Using merger legislation for non-efficiency objectives as an indirect way to increase consumer welfare involves trade-offs with the efficient allocation of resources in the industry. It also fails to take account of flow-on effects from producer gains or profits, such as increased tax revenues, dividends, redistribution of resources and further industry investment (IC, 1992:6).

The pursuit of income-distribution objectives adds uncertainty to the efficiency impact of merger provisions. In any case, they can have only incidental income distribution effects compared with other government policies, including taxes, tariffs, government expenditures and labour market policies (NZBR, 1986). Merger laws will also have a more arbitrary impact on income distribution than direct welfare measures: for example, decisions favouring consumers at the expense of producers, depending on patterns of consumption, may result in larger gains to highincome consumers. A fall in consumer prices caused by policies that do not pro-

\footnotetext{
${ }^{3}$ Tillmanns Butcheries Pty Ltd v Australasian Meat Industry Employees' Union (1979) 42 FLR 331 at 348.

${ }^{4}$ TPC V Ansett Transport Industries (Operations) Pty Ltd \& Ors (1978) ATPR 40-071 at 17,717.
} 
mote efficiency may be offset by falling firm profits, lower investment and employment, and higher interest rates (IC, 1992:6). The total net change in welfare from a proposed merger is a more appropriate benchmark for determining whether it should proceed. Stricter controls over mergers would therefore be warranted only to the extent that mergers resulted in significant overall welfare losses.

\section{The Caltex/Ampol Merger}

The ACCC's blocking of the merger between Caltex and Ampol surprised many industry and media commentators. Despite recent successful transport-industry court cases dealing with pricing and anti-competitive conduct, the ACCC's actions marked a new and stronger level of monitoring, intervention and enforcement of competition laws. Few commentators expected that the proposed rationalisation would breach the 'substantial lessening of competition' test or that the IC (1994) report confirming the competitiveness of the petroleum industry would apparently be ignored. The merger of the two smallest competitors (Ampol with 13 per cent of the market and Caltex 17 per cent), was intended to lower their costs, thus allowing them to compete more effectively with the larger majors: Shell (27 per cent), BP (22 per cent), and Mobil (20 per cent).

How the ACCC applied the five-step approach to this merger is unclear. As the parties did not formally apply for authorisation, the ACCC was not explicitly required to consider the 'public benefit' or efficiency gains (TPC, 1992:6). The lack of transparency in the evaluation process led to media speculation that other goals were being pursued. However, the reasons for the blocking of the merger were issued by press release (TPC, 1995a). These essentially reflected concerns that independents (operators who compete with the oil majors) would be squeezed out of the petrol market.

Yet the presence of one strong independent was a decisive factor in the ACCC not opposing the 1995 Westpac-Challenge Bank merger, which reduced the number of banks in Western Australia from six to five. BankWest was said to be a substantial and profitable competitor on price and service with a 24 per cent market share in deposits and a similar market share of loans in WA. Independent regional banks were thought to add 'diversity, imovation, closeness to customers and price competition' in contrast to the 'look-alike' image of major banks (TPC, 1995a:29). But this glosses over the high degree of competition between the major banks for market share.

\section{Reasons for the ACCC's Decision}

The ACCC justified its decision on a number of grounds (TPC, 1995a):

Refinery exchange agreements and other cooperative arrangements such as joint terminalling between the majors. Refinery exchange agreements allow oil majors to compete in all markets, without additional transport costs. Volumes of petrol are swapped on a litre-for-litre basis between refineries in different States. Some argue 
that independents have difficulty in making supply agreements because of their lack of refineries. But this ignores the current excess capacity of refineries, which makes it profitable for majors to offload excess quantities quickly. The IC (1994:55) found that, on balance, refinery exchange agreements increase competition by reducing transport costs and allowing firms to compete in markets where they do not have refining capacity. Further, joint terminals allow costs of such facilities to be minimised and are not necessarily a result of anticompetitive or collusive behaviour.

The small number of suppliers of petrol and inelastic demand for petrol. According to the Office of Regulation Review (1995:23), the best evidence suggests that although a monopolist may charge a high price, the entry of one or two firms usually results in effective competition. Once a market has three to five suppliers, an additional entrant has little impact on pricing. However, the number of suppliers and the nature of the demand alone are inadequate indicators of market power, and inelastic demand is an ambiguous one. The real question is whether prices have been, or can be, higher than their competitive level. Domestic price increases have lagged behind inflation (IC, 1994:45) and, by international standards, Australia has the seventh-lowest (pre-tax) price (see Figure 1).

\section{Figure 1}

\section{OECD gasoline prices and taxes, 4th quarter 1994}

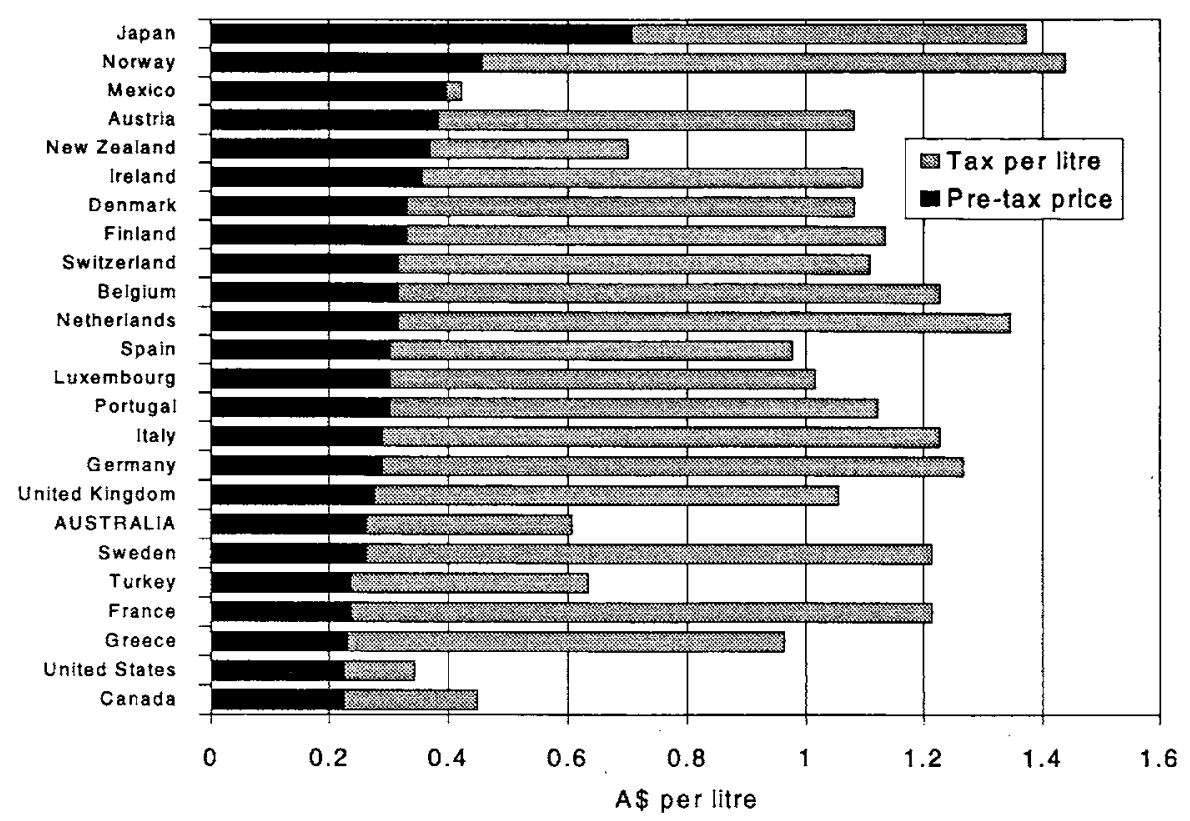

Source: International Energy Agency (1995:xxiv). 
No formal price controls exist on retail petrol prices in Australia. Instead, the Prices Surveillance Authority sets maximum wholesale petrol prices with reference to import parity prices from the Singapore market. The threat of imports is also an effective force providing competitive pressure. Currently, imports are low at around 6 per cent, and excess capacity exists in the domestic industry. Importers in Western Australia and a new importer in Victoria suggest that there are no significant barriers to importing should it become profitable to do so or should domestic shortages occur (Shann, 1995:37). If domestic prices are high and majors are making significant profits, there may be sufficient incentive for independents to invest in terminal facilities for imports and expand distribution networks.

Low levels of excess refining capacity. Currently, Ampol is supplied by other oil majors. An unimpeded merger would have led to Ampol absorbing Caltex's Kurnell refinery's excess capacity. Although independents currently buy from Caltex, total industry refining capacity would remain unchanged. It would be in the commercial interests of other majors to supply independents once Ampol has switched to Caltex, in order to minimise stock build-up while producing close to full capacity. Australian refineries typically operate on an average capacity of about 90 per cent, but this fluctuates with demand conditions, not only for petrol, but for other joint products (IC, 1994:22). Refining is highly capital-intensive and hence has high fixed costs but low variable costs. Oil majors have an incentive to keep output as high as possible. They find it beneficial to produce more petrol at marginal cost and sell it at low prices (as long as they more than cover marginal cost) rather than make no sales at all.

Vertical integration of the majors through ownership interests in distributors and retailers, and tied franchises. Vertical integration is a common feature of many industries because it reduces transaction and administration costs. Whether these arrangements affect competition by allowing majors to exercise control over the market is unclear. Most likely, these agreements do not add to market power, given the existence of other competitors (IC, 1994:60).

Subsidisation by the majors of low retail and wholesale margins through high refining margins. Annual reports consistently show that the petroleum industry is not highly profitable, with low rates of return compared with other processing industries. Four big marketers left during the 1980s. Recent low profit figures suggest strong competition for market share by the five remaining oil majors and the need for rationalisation to achieve cost savings. Presumably, if petrol were a highly profitable market, not only would independents be attracted to invest, but other multinational oil companies would be seeking to enter — not exit — the industry. 
The evident strategies of the majors to constrain independent operators in view of:

- The reduction in the viability of independent operators caused by low wholesale and retail margins. But these conditions are faced by all participants and are consistent with fierce competition.

- A reduction and restriction in supply of petrol from the major refiners to independent wholesalers and distributors. Rather than being part of a 'strategy' to limit competition, this has resulted from the declining excess capacity in the industry. Although this may be reversed with additional investment in refining capacity, such investment is highly dependent on forecast growth in demand as well as the regulatory and economic climate. Imports are also a viable source of supply.

- Restrictions placed on certain companies and people from entering the market and on the use of former retail petrol sites for petrol retailing. The industry has seen a rationalisation at all levels. Retail sites have been reduced from $20,000 \mathrm{in}$ the 1970 s to 9,000 today. In a highly competitive market with low margins, low volume sites are being closed.

- The absence of independent networks of sufficient size to justify the cost of importation and of appropriate facilities for the independent importation of petrol on significant scale (other than in Perth). This is mainly caused by the absence of incentives to invest in networks and facilities in an unprofitable market. If there are regulatory or development approval impediments in setting up import facilities, then these barriers should be addressed directly, not indirectly through merger laws.

The evident strategies of the majors to limit compctition at the wholesale and retail levels. Given the high visibility of petrol prices, oil companies are often subject to public criticism. But pricing 'strategies' are dictated by the nature and structure of the industry and are affected by a number of factors.

\section{Factors Influencing Prices}

The Motor Trades Association of Australia estimates that refineries lose money if operated below 95 per cent capacity (Legislative Assembly for the ACT, 1994:31). But as companies also want high prices to cover capital costs, prices may fluctuate as a result. Surplus is also dumped at high volume retailers close to the refinery, and sold cheaply to independent distributors.

Another factor influencing price cycles is the fact that independents generally have lower costs and may seek volume by undercutting. They must gain enough volume growth to offset the reduction in their margin for petrol. Due to the high degree of substitutability between brands, others lose sales and try to match the 
lower price. Refiners have significant incentives to maintain market share due to the current levels of excess capacity. BP indicated that a 1 per cent increase in market share of petrol is equivalent to $172 \mathrm{~m}$ litres, or $\$ 100 \mathrm{~m}$ in revenue at current pump prices (IC, 1994:85). Oil majors usually offer assistance such as special subsidies to match price falls. Franchisees are usually required to absorb some of the reduction unless price exceeds a determined minimum margin. The level of support varies with conditions in the vicinity of the retailer. Concessions are usually selective; this localises the price war to specific parts of the city, usually the vicinity of the refinery. They can be extended or terminated by the supplier without notice over the phone, but, without these concessions, price wars could not occur. The speed with which the oil majors act depends on how much market share they lose. If they follow quickly, the price cycle may be faster. However, there is usually a delay in responding: otherwise price wars would never start in the first place. If prices always adjusted instantaneously to match the independents, there would be no incentive to undercut to gain a temporary advantage.

Majors may want to keep prices low to punish independents, retain market share and deter future undercutting. Independents share the consequence of price cutting (lower margins) without the benefit of greater volume. When costs become too great, all oil companies tend to remove dealer support and independents usually follow to regain margins. This observed behaviour has been said by consumer groups to indicate the presence of some collusive power held by the oil majors (IC, 1994:3).

Given the complexity of factors that influence the price of petrol, it is unlikely that any particular reason can be singled out as the main cause of petrol price fluctuations. Both supply factors (excess capacity and limited storage) and seasonal demand conditions may influence pricing strategies. It is also difficult to ascertain on the basis of the pattern of price fluctuations whether any collusive behaviour exists. A simultaneous move in price by all oil majors may be a competitive response to a change in market conditions and not necessarily a result of tacit collusion. However, factors such as the exit of a number of refiners, the ability of an independent to import, the entry of a new participant, and the low profitability in the retail and wholesale sectors suggest that competition is strong or collusion between oil majors ineffective. The available economic evidence of present pricing behaviour and the likely effect with one less player was arguably not sufficiently compelling to justify the decision to block the merger between Ampol and Caltex.

\section{Enforceable Undertakings}

After two months of negotiations, Caltex and Ampol made specific, detailed and legally enforceable undertakings under s.87B of the TPA, designed to produce significant structural changes to the advantage of independent operators. These include: the sale of six oil distribution terminals to allow import, storage and distribution of petrol supplies to independent wholesalers and retailers; agreement to supply at least a billion litres of petrol a year to independents on 'reasonable commercial terms'; the sale of a number of distributorships, 20 distribution depots, 35 city 
and 15 country retail sites to independents; and guaranteed direct access by independents with supply agreements to Ampol/Caltex terminal facilities (TPC, 1995b).

The cost of these concessions is estimated by the parties to represent approximately 10 per cent of the total efficiency savings from the merger (between $\$ 500 \mathrm{~m}$ and $\$ 700 \mathrm{~m}$ ) (Shann, 1995). This highlights the ACCC's unprecedented scope for market intervention. The ACCC justifies these undertakings as a 'structural solution' rather than 'behavioural undertakings' on price, quality or service guarantees. In the TPC's 1994-95 Ammual Report, the latter are said to be unlikely to address any anti-competitive effects of a merger because

- the undertakings replace the dynamic effects of competition with regulated outcomes;

- there are limits on the capacity of regulated arrangements to address adequately all dimensions of competitive price, quality and service;

- there are limits on the ACCC's capacity to design a system that is capable of monitoring and enforcing the achievement of price, quality and service guarantees in a satisfactory way;

- the undertakings put the ACCC in the position of an industry or market regulator, which is inappropriate and imposes administrative demands beyond its resources; and

- markets change over time, while regulated outcomes delivered through enforceable undertakings are static (TPC, 1995c:37).

However some of these arguments also apply to 'structural' undertakings. One full-lime employee of the ACCC has been assigned exclusively to monitor and ensure compliance with undertakings given by the parties. Further, unlike the merger and conduct provisions which apply to all participants in the petrol industry, s.87B can in effect be used to impose burdens and conditions on particular companies. It is difficult to justify requiring Caltex/Ampol to supply and sell assets to independents when no other refiner faces such obligations.

Some of these conditions are also unnecessary, since the activities coincide with the commercial interests of the parties. The real question is whether efficiency is enhanced by this type of ACCC intervention. If existing refiners are acting collusively and making supernormal profits, sufficient incentives would exist for new entrants to participate in the Australian petrol industry. There is no reason to favour independents on the assumption that they somehow respond differently to commercial conditions. The ACCC is currently investigating alleged price fixing between independents and one major. This suggests that pricing behaviour, collusive or competitive, is not determined by whether or not a firm is an independent. 
If there are problems with independents gaining access to terminal facilities, due to restrictive work practices such as the Laidely agreement which reserves delivery areas for tanker drivers employed by the majors and members of the Australian Petroleum Agents and Distributors, these undertakings are at best short-term stopgap measures. They do not tackle the underlying barriers (if any) to entry or import competition for all actual and future competitors.

\section{Conclusion}

With a lower threshold test and a willingness to block or delay mergers, the ACCC has demonstrated a willingness to intervene with its unprecedented use of enforceable undertakings. As most recenlly seen with the proposed Foxtel/Australis merger, significant delays can be caused when the ACCC has 'concerns' that s.50 may be breached. Companies planning mergers will need to weigh the benefits of rationalisation against the additional costs of concessions made when bargaining with the ACCC.

As for the ACCC's conduct, there is a need for more transparency in the evaluation process even when authorisation is not sought. More detail of how economics has been specifically applied, and of why arguments put by the parties have been rejected, would provide guidance and certainty for the broader commercial community.

Finally, in terms of wider policy considerations, such actions could serve as a strong disincentive for investment in the domestic market. Even Michael Porter (whose work was quoted by the ACCC to support a strengthening of s.50) warns against interventionist government policies aimed at particular industries. He describes the government's role as inherently partial, and observes that it cannot create competitive firms. Successful government policies create an environment in which any firm can gain a competitive advantage (Porter, 1990:620, 624). The ACCC's power to block mergers is an ineffective instrument when used as an opportunity to re-engineer an industry. If a market is uncompetitive, industry-wide policy reforms, not a piecemeal approach, are needed.

\section{References}

Fels, $\Lambda$. (1995), 'Corporate Governance Issucs and the TPA', address given to the Institute of Corporate Manuagers, 24 March.

Hay, G. \& J. Walker (1993), 'Merger Policy and the 'TPC's Draft Merger Guidelines', Competition and Consumer Law.Journal 1(1): 33-47.

Industry Commission (IC) (1992) Procompetitive Regulation: Discussion Paper, AGPS, Canberra. (1994), Pedrolcum Products, AGPS, Mclboume (Report No. 40).

International Energy Agency (1995), Energy Prices and Taxes, Paris. 


\section{Sandra Navalli}

Laine, C. (1995), 'The H-H Index: A concentration measure taking the consumers point of view', Antitust Bulletin, Summer: 423-32.

Legislative Assembly for the ACT, Standing Committee on Public Accounts (1994), Review of Petrol Supply Arrangements, Canberra (Report No. 13).

New Zealand Business Roundtable (NZBR) (1986), Antitrust in New Zealand: The Case For Reform, Wellington.

Office of Regulation Review (1995), Competition and Retail Banking, a submission to the PSA's Public Inquiry into fees and charges imposed on retail transaction accounts by banks and other financial institutions, March.

Pasternak, L. (1994), "The New Merger Guidelines and s50 of the Trade Practices Act', University of New South Wales Law Jounal 17(1): 73-108.

Porter, M. (1990), The Competitive Advantage of Nations, Macmillan, London.

Prices Surveillance Authority (1995), Using Econometrics In Market Definition and Market Power Assessment, Melbourne, May (Discussion Paper No. 7).

Sham, E. (1995), 'TPC Exercise Tilling at Windmills', Business Review Weekly, 17 April.

Tonking, A. (1992), 'Section 50 - Controlling Mergers in the Future?', Australian Business Law Reทiew 20 (August): 285-301.

Trade Practices Commission (TPC) (1992), Merger Guidelines: Draft for Comment, Canberra.

— (1995a), 'Ampol Caltcx Merger Likely to Breach TPA', Press Release, 2 February.

— (1995b), 'Undertakings Given by Pioneer Intennational Caltex and Ampol Ltd', 28 March.

(1995c), 'Bulletin: Developments in Trade Practices law and work of the TPC', No. 83, October.

I am grateful to Robert Albon for his helpful comments on an earlier version of this article. 